\title{
Interaction between xylanase, glucose oxidase and ascorbic acid on the technological quality of whole wheat bread
}

\author{
Interação entre xilanase, glicose oxidase e ácido ascórbico na qualidade \\ tecnológica de pão elaborado com farinha do trigo integral
}

Camila Batista da Silva ${ }^{\mathrm{I}}$ Eveline Lopes Almeida ${ }^{\mathrm{II}}$ Yoon Kil Chang

ABSTRACT

This study aimed to verify the performance of xylanase and its interaction with oxidants agents (glucose oxidase and ascorbic acid) on the quality of whole wheat bread. The experiment was based on a central composite rotational design and the Response Surface Methodology was used to analyze the results. None of the xylanase, glucose oxidase or ascorbic acid concentrations within the studied range led to a significant difference in the specific volume. The highest moisture content and the lowest firmness values were reported in the bread with lower and intermediate levels of xylanase and larger amounts of glucose oxidase and ascorbic acid. This effect was observed mainly at the end of the storage period. A minimum amount of xylanase (from

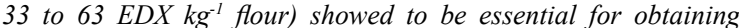
best results. Levels of ascorbic acid above $63 \mathrm{mg} \mathrm{kg}^{-1}$ and glucose oxidase above 91 SRU $\mathrm{kg}^{-1}$ proved to be necessary to offer the beneficial effect of xylanase.

Key words: whole wheat bread, enzymes, oxidants, texture, response surface methodology.

\section{RESUMO}

O objetivo deste estudo foi verificar o desempenho da xilanase e sua interação com agentes oxidantes (glicose oxidase e ácido ascórbico) na qualidade de pão elaborado com farinha do trigo integral. $O$ experimento foi baseado em um delineamento composto central rotacional (DCCR) e a Metodologia de Superficie de Resposta foi utilizada para analisar os resultados. Nenhuma das concentrações de xilanase, glicose oxidase e ácido ascórbico, dentro da faixa estudada, levaram a uma diferença significativa no volume especifico. Mais alto conteúdo de umidade e menor firmeza foram encontrados nos pães com concentrações menores e intermediárias de xilanase e concentrações maiores de glicose oxidase e ácido ascórbico. Este efeito foi observado principalmente no final do periodo de estocagem. Uma quantidade

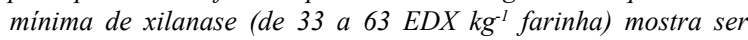
essencial na obtenção dos melhores resultados. Concentrações de ácido ascórbico acima de $63 \mathrm{mg} \mathrm{kg-1}$ e glicose oxidase acima de 91 $S R U \mathrm{~kg}^{-1}$ mostraram ser necessárias para que o efeito benéfico da xilanase fosse observado.

Palavras-chave: pão elaborado com farinha do trigo integral, enzimas, oxidantes, textura, metodologia de superficie de resposta.

\section{INTRODUCTION}

Whole grains, by definition, consist of the intact, ground, cracked or flaked caryopsis, whose principal anatomical components - endosperm, germ and bran - are present in the same relative proportions as they exist in the intact caryopsis (DEVRIES \& FAUBION, 1999). Several epidemiological studies have suggested the existence of a relationship between a high intake of whole-grain products and a reduced risk of developing certain types of cancers, cardiovascular disease, type 2 diabetes and obesity (SLAVIN, 2003).

The processing of whole grains products has certain technological difficulties. Therefore, many additives and technological processing aids are used to influence the structural and physico-chemical

\footnotetext{
'Departamento de Tecnologia de Alimentos, Faculdade de Engenharia de Alimentos, Universidade Estadual de Campinas (Unicamp), Campinas, SP, Brasil.

IDDepartamento de Engenharia Bioquímica, Centro de Tecnologia, Escola de Química, Universidade Federal do Rio de Janeiro (UFRJ), Avenida Athos da Silveira Ramos, 149, Bloco E, Sala E-203, Cidade Universitária, Ilha do Fundão, 21941-909, Rio de Janeiro, RJ, Brasil. E-mail: eveline@eq.ufrj.br. Corresponding author.
} 
characteristics of flour constituents to optimise its functionality in baking. Recently, the use of enzymes to completely or partially replace other additives in food industry has been growing.

Xylanases are used in bakery products due to their beneficial effects on dough properties during mixing and fermentation and on bread quality. The activity of xylanase in dough and bread is related to the solubilisation of insoluble arabinoxylans, which have undesirable properties in bread making (HILLE \& SCHOONEVELD-BERGMANS, 2004). Glucose oxidase is an enzyme that can be used to promote the oxidation of the protein matrix and is attracting considerable interest as a wheatflour dough improver (DUNNEWIND et al., 2002). It catalyses the oxidation of $\beta$-D-glucose into $\beta$-Dgluconolactone in the presence of oxygen, with the latter being converted into hydrogen peroxide. Hydrogen peroxide promotes the oxidation of the $\mathrm{SH}$ groups of two cysteine residues into S-S cross linkages in the gluten matrix (PRIMO-MARTÍN et al., 2005).

Due to studies showing the application of additives and technological processing aids in whole wheat products is scarce; this study proposed to study the influence of added xylanase, glucose oxidase and ascorbic acid on the technological quality of whole wheat bread.

\section{MATERIALS AND METHODS}

To obtain whole wheat flour, cleaned grains were conditioned for up to $14.5 \%$ moisture and then ground in a Brabender Quadrumat Senior (Brabender GmbH \& Co. KG, Duisburg, Germany), passing through the breaking and reduction systems. The whole flour comprised a combination of break flour $(21.36 \%)$, reduction flour (35.02\%), bran $(27.21 \%)$ and short $(13.20 \%)$. It was $15.59 \pm 0.16 \%$ protein $(\mathrm{Nx} 5.7)$, $1.22 \pm 0.01 \%$ ash and $2.28 \pm 0.02 \%$ lipids on a dry basis (AACC Methods 46-13.01 and 08-01.01, and AOAC Method 920.39C, respectively). The water absorption, stability, mixing tolerance index, maximum resistance to extension $(135 \mathrm{~min})$ and extensibility (135min) were $68 \%, 8.5 \mathrm{~min}, 40 \mathrm{UF}$, $810 \mathrm{UE}$ and $112 \mathrm{~mm}$, respectively, and the Falling Number was $320 \pm 4$ seconds (AACC Methods 54-21.02, 54-10.01. and 56-81.03, respectively). The enzymes Pentozyn ${ }^{\circledR} \mathrm{C}$ fungal xylanase $(1,404$ EDX $\mathrm{g}^{-1}$ ) and Glucozyn ${ }^{\circledR} 250$ glucose oxidase (331 SRU g-1) were supplied by Prozyn Indústria e Comércio Ltda (São Paulo, Brazil), and ascorbic acid was supplied by DSM Produtos Nutricionais Brasil Ltda (São Paulo, Brazil).

The following formulation was used to produce the loaves, which was according to ALMEIDA et al. (2013) with some modifications: whole wheat flour (100\%), water $(67.0 \%$ flour basis), instant baker's yeast (2.0\% flour basis), salt (2.0\% flour basis), sugar (4.0\% flour basis), Cargill hydrogenated vegetable fat (3.0\% flour basis), Danisco PANODAN ${ }^{\circledR}$ G20-20 diacetyl tartaric acid esters of mono and diglycerides $(0.3 \%$ flour basis), Roquette Frères vital gluten (4.0\% flour basis), skimmed milk powder (4.0\% flour basis) and Metachem calcium propionate cluster $(0.3 \%$ flour basis). Xylanase (XYL), glucose oxidase (GOX) and ascorbic acid (ASC) were added to the formulation according to a complete factorial experimental design (Table 1). In addition to producing loaves according to the design, loaves were also produced using the control assay (without the addition of the enzymes and with 80 $\mathrm{mg}$ ascorbic acid per $\mathrm{kg}$ flour).

Loaves were prepared according to the modified straight dough method. Batches of $6.5 \mathrm{~kg}$ of whole wheat flour were made. Initially, the ingredients were mixed in an automatic spiral mixer HAE 10 (Hypo, Ferraz de Vasconcelos, Brazil), for $5 \mathrm{~min}$ on low speed and $3 \mathrm{~min}$ on high speed. Next, the dough was divided into $400 \mathrm{~g}$ portions. After resting for $15 \mathrm{~min}$, dough was molded, placed in tins and kept in a proofing chamber 20B (Klimaquip, Pouso Alegre, Brazil), at $30^{\circ} \mathrm{C}$ and $80 \% \mathrm{RH}$ for $80 \mathrm{~min}$. After proofing, dough was placed in a hearth oven $\mathrm{HF}$ 4B (Hypo, Ferraz de Vasconcelos, Brazil), at $160^{\circ} \mathrm{C}$ for 40 minutes. After baking, the loaves were kept at ambient temperature for 1 hour and then conditioned in plastic packages. The following day, loaves were sliced and packed again.

Specific volume was determined, in triplicate one hour after baking, by seed displacement using AACC Method 10-05.01. Bread quality during storage was evaluated by analysing the moisture and texture on the $1^{\text {st }}, 4^{\text {th }}, 7^{\text {th }}$ and $10^{\text {th }}$ days of storage. Moisture content of the loaves was determined in triplicate using AACC Method 44-15.02. The firmness of the bread crumb was performed, in five replicates, according to AACC Method 74-09.01.

The results of the assays that were performed according to the central composite rotational design (CCRD) used to study the effects of the independent variables (XYL, GOX and ASC) were analysed using the STATISTICA 
Table 1 - Specific volumes and crumb moisture levels of whole wheat breads prepared with xylanase, glucose oxidase and ascorbic acid on the $1^{\text {st }}, 4^{\text {th }}, 7^{\text {th }}$ and $10^{\text {th }}$ days of storage.

\begin{tabular}{|c|c|c|c|c|c|c|c|c|}
\hline \multirow{2}{*}{ Assay } & \multirow{2}{*}{ XYL } & \multirow{2}{*}{ GOX } & \multirow{2}{*}{ ASC } & \multirow{2}{*}{$\mathrm{SV}(\mathrm{mL} / \mathrm{g})$} & \multicolumn{4}{|c|}{ 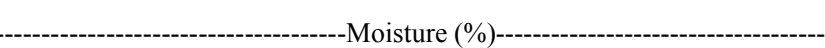 } \\
\hline & & & & & Day 1 & Day 4 & Day 7 & Day 10 \\
\hline 1 & $\begin{array}{l}-1 \\
(33.98)\end{array}$ & $\begin{array}{l}-1 \\
(56.53)\end{array}$ & $\begin{array}{l}-1 \\
(16.19)\end{array}$ & $4.91 \pm 0.21$ & $43.58 \pm 2.81^{\mathrm{a}}$ & $43.04 \pm 0.16^{\mathrm{ab}}$ & $41.81 \pm 0.37^{\mathrm{bc}}$ & $40.75 \pm 0.15^{\circ}$ \\
\hline 2 & $\begin{array}{l}+1 \\
(92.38)\end{array}$ & $\begin{array}{l}-1 \\
(56.53)\end{array}$ & $\begin{array}{l}-1 \\
(16.19)\end{array}$ & $5.10 \pm 0.10$ & $43.81 \pm 0.64^{\mathrm{a}}$ & $43.30 \pm 0.16^{\mathrm{a}}$ & $41.89 \pm 0.28^{b}$ & $40.44 \pm 0.17^{\mathrm{c}}$ \\
\hline 3 & $\begin{array}{l}-1 \\
(33.98)\end{array}$ & $\begin{array}{l}+1 \\
(125.52)\end{array}$ & $\begin{array}{l}-1 \\
(16.19)\end{array}$ & $4.66 \pm 0.03$ & $43.91 \pm 2.33^{\mathrm{a}}$ & $43.25 \pm 0.14^{b}$ & $41.89 \pm 0.24^{\mathrm{c}}$ & $41.44 \pm 0.24^{\mathrm{d}}$ \\
\hline 4 & $\begin{array}{l}+1 \\
(92.38)\end{array}$ & $\begin{array}{l}+1 \\
(125.52)\end{array}$ & $\begin{array}{l}-1 \\
(16.19)\end{array}$ & $4.45 \pm 0.14$ & $43.51 \pm 0.24^{\mathrm{a}}$ & $42.40 \pm 0.29^{b}$ & $41.18 \pm 0.14^{c}$ & $40.20 \pm 0.31^{\mathrm{d}}$ \\
\hline 5 & $\begin{array}{l}-1 \\
(33.98)\end{array}$ & $\begin{array}{l}-1 \\
(56.53)\end{array}$ & $\begin{array}{l}+1 \\
(63.81)\end{array}$ & $4.75 \pm 0.03$ & $44.35 \pm 0.10^{\mathrm{a}}$ & $43.36 \pm 0.19^{b}$ & $41.99 \pm 0.33^{c}$ & $40.35 \pm 0.06^{\mathrm{d}}$ \\
\hline 6 & $\begin{array}{l}+1 \\
(92.38)\end{array}$ & $\begin{array}{l}-1 \\
(56.53)\end{array}$ & $\begin{array}{l}+1 \\
(63.81)\end{array}$ & $4.65 \pm 0.18$ & $43.71 \pm 0.13^{\mathrm{a}}$ & $42.94 \pm 0.08^{\mathrm{b}}$ & $42.13 \pm 0.14^{c}$ & $40.75 \pm 0.19^{d}$ \\
\hline 7 & $\begin{array}{l}-1 \\
(33.98)\end{array}$ & $\begin{array}{l}+1 \\
(125.52)\end{array}$ & $\begin{array}{l}+1 \\
(63.81)\end{array}$ & $4.94 \pm 0.24$ & $43.78 \pm 0.21^{\mathrm{a}}$ & $43.30 \pm 0.31^{\mathrm{b}}$ & $42.43 \pm 0.20^{\mathrm{c}}$ & $41.65 \pm 0.20^{\mathrm{d}}$ \\
\hline 8 & $\begin{array}{l}+1 \\
(92.38)\end{array}$ & $\begin{array}{l}+1 \\
(125.52)\end{array}$ & $\begin{array}{l}+1 \\
(63.81)\end{array}$ & $5.06 \pm 0.18$ & $44.04 \pm 0.12^{\mathrm{a}}$ & $43.73 \pm 0.85^{\mathrm{a}}$ & $41.79 \pm 0.20^{b}$ & $40.50 \pm 0.26^{\mathrm{c}}$ \\
\hline 9 & $\begin{array}{l}-1.68 \\
(14.04)\end{array}$ & $\begin{array}{l}0 \\
(91.03)\end{array}$ & $\begin{array}{l}0 \\
(40)\end{array}$ & $4.38 \pm 0.05$ & $43.91 \pm 0.38^{\mathrm{a}}$ & $43.03 \pm 0.17^{b}$ & $42.08 \pm 0.51^{\mathrm{c}}$ & $40.73 \pm 0.63^{d}$ \\
\hline 10 & $\begin{array}{l}+1.68 \\
(112.32)\end{array}$ & $\begin{array}{l}0 \\
(91.03)\end{array}$ & $\begin{array}{l}0 \\
(40)\end{array}$ & $4.85 \pm 0.17$ & $43.58 \pm 0.28^{\mathrm{a}}$ & $42.88 \pm 0.25^{\mathrm{b}}$ & $41.46 \pm 0.19^{c}$ & $40.17 \pm 0.31^{\mathrm{d}}$ \\
\hline 11 & $\begin{array}{l}0 \\
(63.18)\end{array}$ & $\begin{array}{l}-1.68 \\
(33.10)\end{array}$ & $\begin{array}{l}0 \\
(40)\end{array}$ & $4.81 \pm 0.12$ & $43.95 \pm 0.24^{\mathrm{a}}$ & $43.01 \pm 0.27^{b}$ & $41.47 \pm 0.11^{\mathrm{c}}$ & $40.66 \pm 0.41^{\mathrm{d}}$ \\
\hline 12 & $\begin{array}{l}0 \\
(63.18)\end{array}$ & $\begin{array}{l}+1.68 \\
(148.95)\end{array}$ & $\begin{array}{l}0 \\
(40)\end{array}$ & $5.10 \pm 0.02$ & $43.96 \pm 0.08^{a}$ & $43.32 \pm 0.18^{b}$ & $42.36 \pm 0.16^{\mathrm{c}}$ & $41.45 \pm 0.20^{\mathrm{d}}$ \\
\hline 13 & $\begin{array}{l}0 \\
(63.18)\end{array}$ & $\begin{array}{l}0 \\
(91.03)\end{array}$ & $\begin{array}{l}-1.68 \\
(0)\end{array}$ & $4.80 \pm 0.12$ & $43.45 \pm 0.99^{\mathrm{a}}$ & $43.08 \pm 0.20^{\mathrm{a}}$ & $41.61 \pm 0.11^{b}$ & $40.65 \pm 0.30^{\circ}$ \\
\hline 14 & $\begin{array}{l}0 \\
(63.18)\end{array}$ & $\begin{array}{l}0 \\
(91.03)\end{array}$ & $\begin{array}{l}+1.68 \\
(80)\end{array}$ & $4.48 \pm 0.10$ & $44.54 \pm 0.08^{\mathrm{a}}$ & $43.88 \pm 0.38^{b}$ & $42.45 \pm 0.20^{\mathrm{c}}$ & $41.40 \pm 0.08^{\mathrm{d}}$ \\
\hline 15 & $\begin{array}{l}0 \\
(63.18)\end{array}$ & $\begin{array}{l}0 \\
(91.03)\end{array}$ & $\begin{array}{l}0 \\
(40)\end{array}$ & $4.86 \pm 0.08$ & $43.55 \pm 1.78^{a}$ & $43.27 \pm 0.17^{b}$ & $41.85 \pm 0.11^{\mathrm{c}}$ & $40.50 \pm 0.25^{\mathrm{d}}$ \\
\hline 16 & $\begin{array}{l}0 \\
(63.18)\end{array}$ & $\begin{array}{l}0 \\
(91.03)\end{array}$ & $\begin{array}{l}0 \\
(40)\end{array}$ & $4.88 \pm 0.18$ & $43.87 \pm 0.10^{\mathrm{a}}$ & $43.6 \pm 0.18^{b}$ & $41.88 \pm 0.15^{\mathrm{c}}$ & $40.40 \pm 0.18^{d}$ \\
\hline 17 & $\begin{array}{l}0 \\
(63.18)\end{array}$ & $\begin{array}{l}0 \\
(91.03)\end{array}$ & $\begin{array}{l}0 \\
(40)\end{array}$ & $4.90 \pm 0,15$ & $43.81 \pm 0.09^{\mathrm{a}}$ & $43.55 \pm 0.15^{b}$ & $41.83 \pm 0.19^{c}$ & $40.39 \pm 0.19^{d}$ \\
\hline $\mathrm{C}$ & $\begin{array}{l}--- \\
(0)\end{array}$ & $\begin{array}{l}--- \\
(0)\end{array}$ & $\begin{array}{l}--- \\
(80)\end{array}$ & $4.67 \pm 0.11$ & $44.08 \pm 0.15^{\mathrm{a}}$ & $43.44 \pm 0.22^{b}$ & $42.09 \pm 0.09^{\mathrm{c}}$ & $40.81 \pm 0.22^{d}$ \\
\hline
\end{tabular}

Mean \pm standard deviation, $\mathrm{n}=3 . \mathrm{XYL}=$ xylanase; $\mathrm{GOX}=$ glucose oxidase; $\mathrm{ASC}=$ ascorbic acid; $\mathrm{SV}=$ specific volume; $\mathrm{C}=$ control Values in brackets correspond to the amounts of xylanase, glucose oxidase and ascorbic acid in EDX kg $\mathrm{El}^{-1} \mathrm{flou}_{\mathrm{SRU} \mathrm{kg}} \mathrm{SR}^{-1}$ flour and mg/kg flour, respectively. Means followed by the same superscripted letter on the same line are not significantly different according to Tukey's test $(\mathrm{P}<0.10)$.

7.0 software package, which permitted analysis via Response Surface Methodology. Responses or dependent variables were the bread quality characteristics (specific volume, moisture and firmness). Mathematical models were generated to explain these responses using coded values for the independent variables, where $\mathrm{XYL}=$ the coded value $(-\alpha$ to $+\alpha)$ of the amount of xylanase; $\mathrm{GOX}=$ the coded value $(-\alpha$ to + $\alpha)$ of the amount of glucose oxidase; ASC $=$ the coded value $(-\alpha$ to $+\alpha)$ of the amount of ascorbic acid; Fcalc $=$ calculated F; and Ftab $=$ tabled F. Mathematical models were expressed only with the significant variables. To verify 
the differences of moisture and texture during storage, results were subjected to analysis of variance (ANOVA) and Tukey's test, if necessary. Least significant differences at $\mathrm{P}<0.10$ were used to compare the sample means.

\section{RESULTS AND DISCUSSION}

\section{Specific volume}

The specific volumes varied between 4.38 and $5.10 \mathrm{~mL} \mathrm{~g}^{-1}$ (Table 1). The control loaf had a specific volume of $4.67 \mathrm{~mL} \mathrm{~g}^{-1}$, which is within the range of values that were reported for the specific volume in the trials of the experimental design. It was not possible to establish a predictive model for the specific volume as a function of the variables studied. This indicates that this parameter was within the range of the mean value and its standard deviation regardless of the amounts of XYL, GOX and ASC that were added. Therefore, the use of any amount of XYL, GOX and ASC within the range studied would not lead to a significant difference in the specific volume of the end product.

Several authors showed that the specific volume of breads were increased by XYL (SHAH et al., 2006; JIANG et al., 2008). The enzyme XYL hydrolizes water-unextractable arabinoxylans (WU-AX) in wheat flour, which may cause physical disruption of the gluten, i.e, can disrupt the gluten network (AUTIO, 2006). Further, by the action of this enzyme there is a better redistribution of the water phase to the phase of pentosans (gluten becomes more extensible), resulting in improved bread volume (KATINA, 2003). In relation to GOX and ASC, researches showed that these additives at lower concentrations increased the specific volume due to oxidation effect on gluten network and at higher concentrations decrease the specific volume due to over-oxidation effect (BONET et al., 2006). However, similar to our study, others researches observed that XYL (ALMEIDA \& CHANG, 2012), GOX (RASIAH et al., 2005) and ASC (GUJRAL et al., 2003) had no effect on the volume or specific volume. In our study, this fact could have been due to the high amount of vital gluten used in basis formulation ( $4 \%$ basis flour), which probably masked the effects of additives. Vital gluten helped to maintain product volume. The addition of vital gluten is very important when whole wheat bread is produced because the strength of the dough is weakened by the presence of bran and germ. Good volume for whole wheat bread is obtained with the addition of $5 \%$ or more of vital gluten (LEYN, 2014).

Moisture content

The moisture content of all the loaves decreased as the storage time increased $(\mathrm{P}<0.10)$ (Table 1). On the $1^{\text {st }}$ and $4^{\text {th }}$ days of storage, it was not possible to establish a predictive model for the moisture content of loaves as a function of the variables studied $(\mathrm{P}<0.10)$. Therefore, any amount of XYL, GOX and ASC within the range studied would not lead to a significant difference in the moisture content of the end product. On the $7^{\text {th }}$ and $10^{\text {th }}$ days of storage, the moisture content was affected by the added enzymes and ASC. Mathematical models were generated to describe the behaviour of the moisture content as a function of the amount of XYL, GOX and ASC added, within the ranges studied (Equations 1 and 2). These models showed that ASC and GOX had a positive effect and XYL had a negative effect on the moisture content on the $7^{\text {th }}$ and $10^{\text {th }}$ days of storage, as evidenced through the analysis of the response surfaces generated by the models on the $7^{\text {th }}$ and $10^{\text {th }}$ days of storage (figures not shown). They showed higher moisture with higher concentrations of ASC and GOX and lower concentrations of XYL. Adverse effects of XYL on moisture have previously been reported in the literature. In some studies, XYL increased the moisture content (SHAH et al., 2006) whereas another study reported a decreased in crumb moisture (COURTIN et al., 2001).

Crumb moisture $\quad($ day 7$)=41.89-0.16$ XYL +0.22 ASC - 0.20 XYL GOX

$\left(r^{2}=0.6884 ;\right.$ Fcalc $/$ Ftab $\left.=3.74\right)$

Crumb moisture $($ day 10$)=40.42-0.24 \mathrm{XYL}+0.21$ $\mathrm{GOX}+0.20 \mathrm{GOX}^{2}+0.12 \mathrm{ASC}+0.19 \mathrm{ASC}^{2}-0.31$ XYL GOX

$\left(r^{2}=0.8926 ;\right.$ Fcalc $/$ Ftab $\left.=5.63\right)$

Arabinoxylans (AX) comprised 2-3\% of wheat flour and above $5 \%$ of the whole wheat flour (COLLINS et al., 2006). Water-unextractable arabinoxylans (WU-AX) retained water 10 times their weight and the water-extractable arabinoxylans (WE-AX) can retain water 4-5 times their weight (FORMAN, 2004). The XYL hydrolyze WU-AX, resulted in loss of water retention capability and increased viscosity of the 
aqueous medium due to the solubilization of AX. They also degrade WE-AX with low molecular weight reducing the viscosity-inducing properties and partially impairing the gelation ability (COURTIN \& DELCOUR, 2001). Initially, the main hydrolysis products are $\beta$-D-xylopyranosyl oligomers, but in a more advanced stage, small molecules such as mono-, di- and trisaccharides of $\beta$-D-xylopyranosyl may be produced (BUTT et al., 2008). Release of compounds of low molecular weight from WE-AX is mainly related to action of XYL from fungal origin (as used in this study). The XYL of this origin, besides hydrolyzing regions of chain without branch of $A X$, can also hydrolyze the branched areas of AX (COURTIN \& DELCOUR, 2001). In this respect, it is expected a less water retention due to the action of XYL. Lower molecular weight arabinoxylans have less ability to retain water.

GOX and ASC appear to reverse this effect of "water release" due to the action of XYL. Upon oxidation, the WE-AX created an elastic gel which greatly increases the water binding capacity of AX (FORMAN, 2004). Therefore, in the presence of XYL, larger amounts of oxidizing agents provided higher moisture values. This effect was observed at low concentrations of XYL (below $63 \mathrm{EDX} / \mathrm{kg}$ flour). At high concentrations (above $63 \mathrm{EDX} / \mathrm{kg}$ flour), it seems that no amount of oxidant is enough to "reverse" the XYL effect to release water, causing lower moisture contents. However, it is worth mentioning that the presence of XYL is required to have increased moisture retention by oxidants.

\section{Firmness}

The different combinations of XYL, GOX and ASC changed the crumb texture. The firmness of all loaves increased gradually as the storage time increased $(\mathrm{P}<0.10)$. Mathematical models $(\mathrm{P}<0.10)$ were generated to describe the behaviour of the firmness on the $1^{\text {st }}, 4^{\text {th }}, 7^{\text {th }}$ and $10^{\text {th }}$ days of storage (Equations 3 to 6).

Firmness $($ day 1$)=334.92-29.00$ ASC -34.78 XYL ASC - 25.51 GOX ASC

$\left(\mathrm{r}^{2}=0.7598 ;\right.$ Fcalc $/$ Ftab $\left.=5.36\right)$

Firmness $($ day 4$)=458.77+36.20 \mathrm{XYL}^{2}+15.11$ GOX - 32.75 ASC - 11.34 ASC $^{2}+16.01$ XYL GOX - 31.69 XYL ASC - 31.80 GOX ASC

$\left(r^{2}=0.9565 ;\right.$ Fcalc $/$ Ftab $\left.=8.49\right)$
Firmness $($ day 7$)=579.37+29.89 \mathrm{XYL}^{2}$ - 22.89 ASC + 23.03 XYL GOX - 43.69 XYL ASC 32.05 GOX ASC

$\left(r^{2}=0.8159 ;\right.$ Fcalc $/$ Ftab $\left.=3.98\right)$

Firmness $($ day 10$)=684.09+50.30 \mathrm{XYL}^{2}$ - 22.31 ASC + 32.05 XYL GOX - 48.03 XYL ASC

$\left(r^{2}=0.8019 ;\right.$ Fcalc $/$ Ftab $\left.=4.90\right)$

The response surfaces generated by these models (Figure 1) indicate that, in general, formulations with higher concentrations of ASC (above $63 \mathrm{mg} / \mathrm{kg}$ flour) and GOX (above 91 SRU $\mathrm{kg}^{-1}$ flour) and intermediate levels of XYL (between 33 to $92 \mathrm{EDX} \mathrm{kg}^{-1}$ flour) resulted in loaves with a softer crumb texture (lower values for firmness) throughout the period of storage. This result is according to those obtained in moisture content. Higher concentrations of oxidizing agents could act on WE-AX. With the gel formation, higher amount of water is retained and the crumb is softer. The antifirming effect of GOX also is attributed to the water retention in the interchange associations between $\mathrm{AX}$ and gluten in protein matrix that are established due to the action of this enzyme (BONET et al., 2006). Besides, due to the degradation of cell wall components by XYL, alteration of the distribution of water among starch, gluten and bran particles occured during storage (KATINA et al., 2006). WE-AX can delay amylose aggregation (GRAY \& BEMILLER, 2003) and consequently the starch retrogradation.

\section{CONCLUSION}

The quality of the whole wheat bread was improved by adding XYL, GOX and ASC to the whole wheat flour. Since the whole wheat flour has greater amount of AX compared with white flour, a minimal amount of XYL (between 33 to 63 EDX kg-1 flour) appeared to be essential for best results of moisture and texture of loaf bread made with whole wheat flour, especially during the end of shelf life. However, the XYL should be used in the correct amount (no excess) and in combination with oxidizing agents. High concentrations of ASC (above $63 \mathrm{mg} \mathrm{kg}^{-1}$ ) and GOX (above $91 \mathrm{SRU} \mathrm{kg}^{-1}$ ) are necessary to compose the beneficial effect of XYL. These additives were shown to have an interaction effect on the quality of bread. Results showed that the whole wheat flour that was used, with the 
(I)

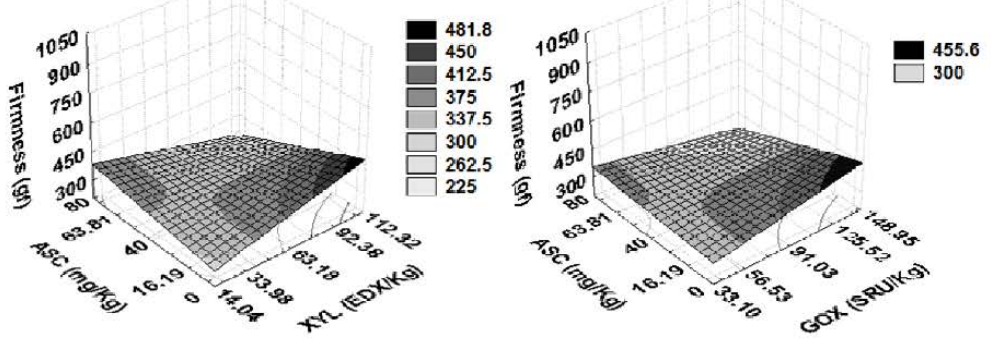

(b)

(c)

(II)

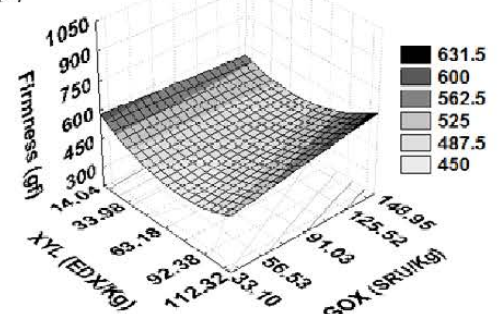

(a)

(III)

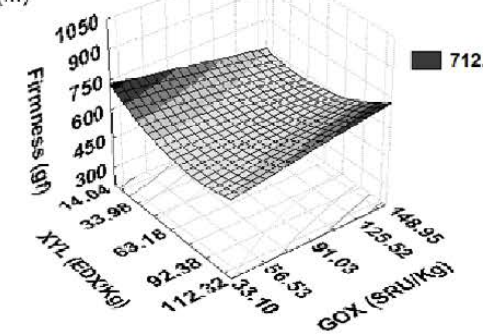

(a)

(IV)

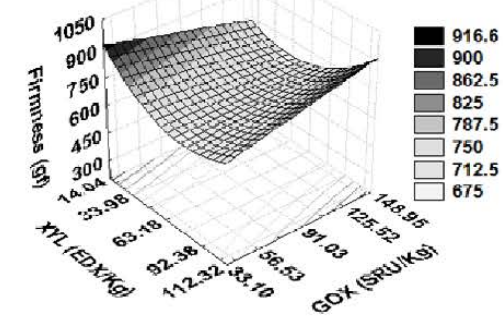

(a)

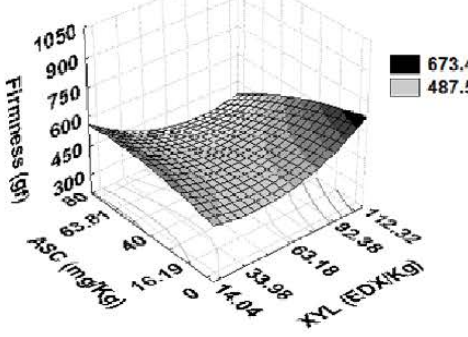

(b)

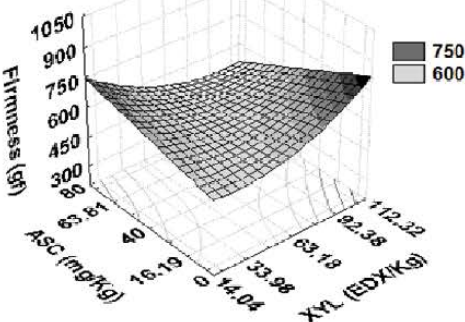

(b)

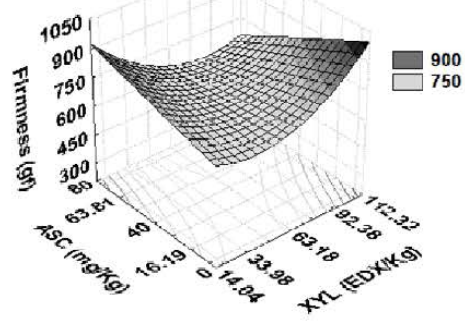

(b)

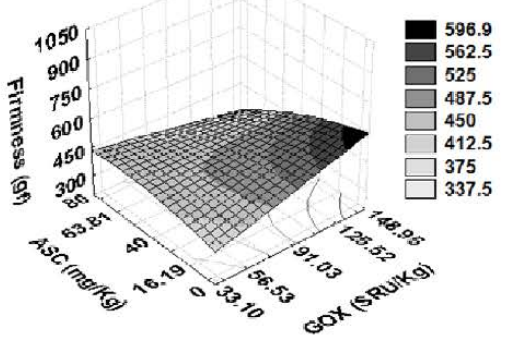

(c)

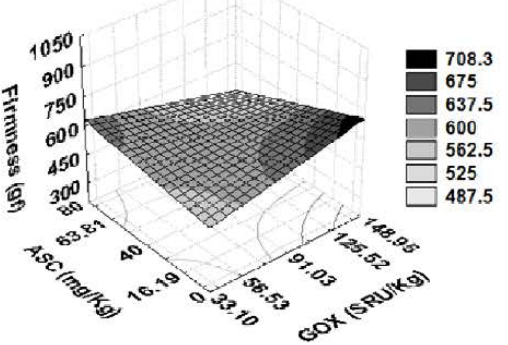

(c)

Figure 1 - Response surfaces for the firmness of the loaves on the (I) $1^{\text {st }}$, (II) $4^{\text {th }}$, (III) $7^{\text {th }}$ and (IV) $10^{\text {th }}$ of storage as a function of (a) xylanase and glucose oxidase; (b) xylanase and ascorbic acid and (c) glucose oxidase and ascorbic acid, with the third variable fixed at 0. $\mathrm{XYL}=$ xylanase GOX $=$ glucose oxidase; $\mathrm{ASC}=$ ascorbic acid.

addition of XYL, GOX and ASC, has considerable potential for producing high-quality loaf bread.

\section{ACKNOWLEDGMENTS}

The authors would like to thank Prozyn Indústria e Comércio Ltda for kindly donating the enzymes and the funding agency Coordenação de Aperfeiçoamento de Pessoal de Nível Superior (CAPES) for granting a scholarship to authors.

\section{REFERENCES}

AACC (AMERICAN ASSOCIATION OF CEREAL CHEMISTS). Approved methods of analysis. 11.ed. St. Paul: Methods 08-

Ciência Rural, v.46, n.12, dez, 2016. 
01.01, 10-05.01, 44-15.02, 46-13.01, 54-10.01, 54-21.02, 56-81.03 and 74-09.01. Available from: <http://methods.aaccnet.org/>. Accessed: Sept. 08, 2015.

ALMEIDA, E.L.; CHANG, Y.K. Effect of the addition of enzymes on the quality of frozen pre-baked French bread substituted with whole wheat flour. LWT - Food Science and Technology, v.49, p.64-72, 2012. Available from: $\quad<\mathrm{http}: / / \mathrm{www} . \mathrm{sciencedirect.com} /$ science/article/ pii/S0023643812001909>. Accessed: Sept. 08, 2015. doi: 10.1016/j.1wt.2012.04.019.

ALMEIDA, E.L. et al. Dietary fibre sources in bread: influence on technological quality. LWT - Food Science and Technology, v.50, p.545-553, 2013. Available from: <https:// www.researchgate.net/publication/232659656_Dietary_ fibre sources in bread Influence on technological quality>. Accessed: Mar. 30, 2016. doi: 10.1016/j. lwt.2012.08.012.

AOAC (ASSOCIATION OF OFFICIAL ANALYTICAL CHEMISTS). Official methods of analysis. 20.ed. Washington: Method 920.39C. Available from: <http://www.aoac.org/ imis $15 \mathrm{prod} / \mathrm{AOAC} /$ Publications/Official Methods of Analysis/ AOAC_Member/Pubs/OMA/AOAC_Official_Methods_of Analysis.aspx?hkey=5142c478-ab50-4856-8939-a7a491756f48> . Accessed: Mar. 30, 2016.

AUTIO, K. Effects of cell wall components on the functionality of wheat gluten. Biotechnology Advances, v.24, p. 633-635, 2006 Available from: $<\mathrm{http} / / \mathrm{www}$. sciencedirect.com/science/article/pii/ S0734975006000917>. Accessed: Sept. 08, 2015. doi: 10.1016/j. biotechadv.2006.07.002

BONET, A. et al. Glucose oxidase effect on dough rheology and bread quality: a study from macroscopic to molecular level. Food Chemistry, v.99, p.408-415, 2006. Available from: <http://www.sciencedirect.com/science/article/ pii/S0308814605006254>. Accessed: Sept. 08, 2015. doi: 10.1016/j.foodchem.2005.07.043.

BUTT, M.S. et al. Xylanases and their applications in baking industry. Food Technology and Biotechnology, v.46, p.2231, 2008. Available from: <http://www.ftb.com.hr/index. php/archives/70-volume-46-issue-no-1/292>. Accessed: Sept. 08, 2015.

COLLINS, T. et al. Use of glycoside hydrolase family 8 xylanases in baking. Journal of Cereal Science, v.43, p.79-84, 2006. Available from: <http://www2.ulg.ac.be/biochlab/pdf/pub/jcs_2006.pdf>. Accessed: Sept. 08, 2015. doi: 10.1016/j.jcs.2005.08.002.

COURTIN, C.M.; DELCOUR, J.A. Relative activity of endoxylanases towards water-extractable and water-unextractable arabinoxylan. Journal of Cereal Science, v.33, p.301-312, 2001. Available from: $<$ http://www.sciencedirect.com/science/article/pii/ S0733521000903540>. Accessed: Sept. 08, 2015. doi: 10.1006/ jcrs. 2000.0354

COURTIN, C.M. et al. Use of two endoxylanases with different substrate selectivity for understanding arabinoxylan funtionality in wheat flour breadmaking. Cereal Chemistry, v.78, p.564-571, 2001. Available from: <http://cerealchemistry.aaccnet.org/doi/ abs/10.1094/CCHEM.2001.78.5.564>. Accessed: Sept. 08, 2015. doi: 10.1094/CCHEM.2001.78.5.564.
DEVRIES, J.W.; FAUBION, J.M. Defining dietary fiber: a report on the AACC/ILSI NA consensus workshop. Cereal Foods World, v.44, p.506-507, 1999. Available from: <http://www. aaccnet.org/initiatives/definitions/documents/dietaryfiber/dfdef. pdf $>$. Accessed: Sept. 08, 2015.

DUNNEWIND, B. et al. Effect of oxidative enzymes on bulk rheological properties of wheat flour doughs. Journal of Cereal Science, v.36, p.357-366, 2002. Available from: $<\mathrm{http}$ ///www.sciencedirect.com/science/article/pii/ S0733521002904716>. Accessed: Sept. 08, 2015. doi: $10.1006 /$ jers.2002.0471.

FORMAN, T. Enzymes used in bread baking: an application update. AIB Technical Bulletin, v.XXVI, p.1-12, 2004. Available from: <https://www.aibonline.org/aibOnline secure.aibonline.org $/ \mathrm{php} /$ web-search.aspx? Simple=Enzymes $>$. Accessed: Sept. 08, 2015.

GRAY, J.A.; BEMILLER, J.N. Bread Staling: molecular basis and control. Comprehensive Reviews in Food Science and Food Safety, v.2, p.1-21, 2003. Available from: $<\mathrm{http}: / /$ onlinelibrary. wiley.com/doi/10.1111/j.1541-4337.2003.tb00011.x/abstract>. Accessed: Sept. 08, 2015. doi: 10.1111/j.1541-4337.2003. tb00011.x.

GUJRAL, H.S. et al. Note: effect of barley flour, wet gluten and ascorbic acid on bread crumb texture. Food Science and Technology International, v.9, p.17-21, 2003. Available from: $<$ http://fst.sagepub.com/content/9/1/17.abstract $>$. Accessed: Sept. 08, 2015. doi: 10.1177/1082013203009001003.

HILLE， J.D.R.; SCHOONEVELD-BERGMANS， M.E.F. Hemicellulases and their synergism in breadmaking. Cereal Foods World, v.49, p.283-286, 2004. Available from: <http://agris fao.org/agris-search/search.do?recordID=US201300960142>. Accessed: Sept. 08, 2015.

JIANG, Z. et al. Effect of the thermostable xylanase B (XynB) from Thermotoga maritima on the quality of frozen partially baked bread. Journal of Cereal Science, v.47, p.172-179, 2008. Available from: $<$ http://www.sciencedirect.com/science/article/pii/ S0733521007000616>. Accessed: Sept. 08, 2015. doi: 10.1016/j. jcs.2007.03.013.

KATINA, K. High-fibre baking. In: CAUVAIN, S.P. Breadmaking improving quality. Boca Raton: CRC, 2003. Cap.23, p.487-499.

KATINA, K. et al. Effects of sourdough and enzymes on staling of high-fibre wheat bread. LWT - Food Science and Technology, v.39, p.479-491, 2006. Available from: $<\mathrm{http}: / / \mathrm{www}$.sciencedirect.com/science/article/pii/ S0023643805000654>. Accessed: Sept. 08, 2015. doi: 10.1016/j.1wt.2005.03.013.

LEYN, I.D. Other functional additives. In: ZHOU, W.; HUI, Y.H. Bakery products: science and technology. New Jersey: WileyBlackwell, 2014. Cap.14, p.295-306.

PRIMO-MARTÍN, C. et al. An explanation for the combined effect of xylanase - glucose oxidase in dough systems. Journal of the Science of Food and Agriculture, v.85, p.11861196, 2005. Available from: <http://onlinelibrary.wiley.com/ doi/10.1002/jsfa.2107/abstract>. Accessed: Sept. 08, 2015. doi: $10.1002 /$ jsfa. 2107 
RASIAH. I.A. et al. Crosslinking of wheat dough proteins by glucose oxidase and the resulting effects on bread and croissants. Food Chemistry, v.89, p.325-332, 2005. Available from: <http://www.sciencedirect.com/science/article/pii/ S0308814604002031>. Accessed: Sept. 08, 2015. doi: 10.1016/j. foodchem.2004.02.052.

SHAH, A.R. et al. Improvement of the quality of whole wheat bread by supplementation of xylanase from Aspergillus foetidus. Bioresource Technology, v.97, p.2047-2053, 2006. Available from: $<$ http://www.sciencedirect.com/science/article/pii/ S0960852405004815>. Accessed: Sept. 08, 2015. doi: 10.1016/j. biortech.2005.10.006.

SLAVIN, J. Why whole grains are protective: biological mechanisms. Proceedings of the Nutrition Society, v.62, p.129134, 2003. Available from: <http://journals.cambridge.org/ action $/$ displayAbstract fromPage $=$ online $\&$ aid $=807108 \&$ fileId $=$ S0029665103000211 $>$. Accessed: Sept. 08, 2015. doi: 10.1079/ PNS2002221. 